NASA/TM-2002-211633

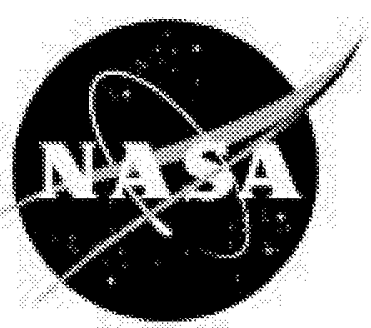

\title{
Evaluation of Sc-Bearing Aluminum Alloy C557 for Aerospace Applications
}

Marcia S. Domack and Dennis L. Dicus

Langley Research Center, Hampton, Virginia 


\section{The NASA STI Program Office ... in Profile}

Since its founding, NASA has been dedicated to the advancement of aeronautics and space science. The NASA Scientific and Technical Information (STI) Program Office plays a key part in helping NASA maintain this important role.

The NASA STI Program Office is operated by Langley Research Center, the lead center for NASA's scientific and technical information. The NASA STI Program Office provides access to the NASA STI Database, the largest collection of aeronautical and space science STI in the world. The Program Office is also NASA's institutional mechanism for disseminating the results of its research and development activities. These results are published by NASA in the NASA STI Report Series, which includes the following report types:

- TECHNICAL PUBLICATION. Reports of completed research or a major significant phase of research that present the results of NASA programs and include extensive data or theoretical analysis. Includes compilations of significant scientific and technical data and information deemed to be of continuing reference value. NASA counterpart of peer-reviewed formal professional papers, but having less stringent limitations on manuscript length and extent of graphic presentations.

- TECHNICAL MEMORANDUM. Scientific and technical findings that are preliminary or of specialized interest, e.g., quick release reports, working papers, and bibliographies that contain minimal annotation. Does not contain extensive analysis.

- CONTRACTOR REPORT. Scientific and technical findings by NASA-sponsored contractors and grantees.
- CONFERENCE PUBLICATION. Collected papers from scientific and technical conferences, symposia, seminars, or other meetings sponsored or co-sponsored by NASA.

- SPECIAL PUBLICATION. Scientific, technical, or historical information from NASA programs, projects, and missions, often concerned with subjects having substantial public interest.

- TECHNICAL TRANSLATION. Englishlanguage translations of foreign scientific and technical material pertinent to NASA's mission.

Specialized services that complement the STI Program Office's diverse offerings include creating custom thesauri, building customized databases, organizing and publishing research results ... even providing videos.

For more information about the NASA STI Program Office, see the following:

- Access the NASA STI Program Home Page at $h t t p: / / w w w . s t i . n a s a . g o v$

- Email your question via the Internet to help@sti.nasa.gov

- Fax your question to the NASA STI Help Desk at (301) 621-0134

- Telephone the NASA STI Help Desk at (301) 621-0390

- Write to:

NASA STI Help Desk NASA Center for AeroSpace Information 7121 Standard Drive Hanover, MD 21076-1320 
NASA/TM-2002-211633

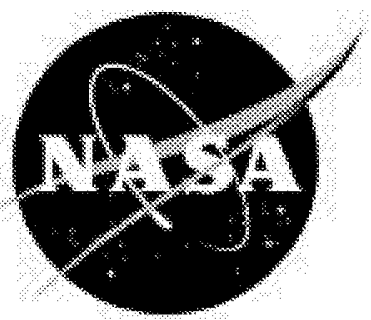

\section{Evaluation of Sc-Bearing Aluminum Alloy C557 for Aerospace Applications}

Marcia S. Domack and Dennis L. Dicus

Langley Research Center, Hampton, Virginia

National Aeronautics and

Space Administration

Langley Research Center

Hampton, Virginia 23681-2199

April 2002 
The use of trademarks or names of manufacturers in this report is for accurate reporting and does not constitute an official endorsement, either expressed or implied, of such products or manufacturers by the National Aeronautics and Space Administration.

Available from:

NASA Center for AeroSpace Information (CASI) 7121 Standard Drive

Hanover, MD 21076-1320

(301) 621-0390
National Technical Information Service (NTIS) 5285 Port Royal Road

Springfield, VA 22161-2171

(703) 605-6000 
Abstract. The performance of the Al-Mg-Sc alloy C557 was evaluated to assess its potential for a broad range of aerospace applications, including airframe and launch vehicle structures. Of specific interest were mechanical properties at anticipated service temperatures and thermal stability of the alloy. Performance was compared with conventional airframe aluminum alloys and with other emerging aluminum alloys developed for specific service environments. Mechanical properties and metallurgical structure were evaluated for commercially rolled sheet in the as-received $\mathrm{H} 116$ condition and after thermal exposures at $107^{\circ} \mathrm{C}$. Metallurgical analyses were performed to define grain morphology and texture, strengthening precipitates, and to assess the effect of thermal exposure.

Introduction. Wrought, non-heat-treatable aluminum-magnesium alloys are potential candidates for structural applications because of their low density, good weldability, and excellent corrosion resistance [1]. The addition of scandium has been shown to increase the strength while maintaining the ductility of aluminum-magnesium alloys [2,3]. Additions of scandium and zirconium to Al-Mg alloys synergystically promote strengthening and result in higher strengths than either $\mathrm{Sc}$ or $\mathrm{Zr}$ additions produce alone [4]. In wrought Al-Mg-Sc alloys with $\mathrm{Zr}$ additions, strengthening occurs primarily by development of coherent $\mathrm{Al}_{3} \mathrm{Sc}$ and $\mathrm{Al}_{3} \mathrm{Zr}$ dispersoids. Additional strengthening is achieved by grain refinement, as the dispersoids inhibit recrystallization during working [4].

The moderate strength level achieved in Al-Mg-Sc alloys combined with the inherent corrosion resistance of the Al-Mg system makes these alloys attractive for airframe structural applications. Sc-bearing dispersoids are inherently thermally stable [5], which enables consideration for structural applications where extended elevated temperatures are anticipated. However, in alloys with magnesium levels above about $3.5 \%$, precipitation of the $\beta$ phase, $\mathrm{Al}_{8} \mathrm{Mg}_{5}$, can occur during thermal exposure and has been shown to be detrimental to corrosion resistance [5]. Limited data available at cryogenic temperatures [2] suggests that $\mathrm{Al}-\mathrm{Mg}-\mathrm{Sc}$ alloys are suitable for service down to liquid hydrogen temperatures.

In the current study, the Al-Mg-Sc alloy C557 was evaluated to assess its potential for a broad range of aerospace applications. Particular emphasis is placed on strength-toughness behavior at temperatures from $-184^{\circ} \mathrm{C}$ to $107^{\circ} \mathrm{C}$ to establish service temperature applicability and after exposures up to 10,000 hours at $107^{\circ} \mathrm{C}$ to evaluate thermal stability.

\section{Materials}

The material evaluated was produced by Alcoa as a $4,500 \mathrm{~kg}(10,000 \mathrm{lb})$ commercial scale ingot. Proprietary thermomechanical processing was used to produce rolled sheets, $1.22 \mathrm{~m} \mathrm{x}$ $3.66 \mathrm{~m}$, both $1.6 \mathrm{~mm}$ and $2.3 \mathrm{~mm}$ thick, in the H116 condition. The thermomechanical processing schedule was tailored to optimize the sheet for superplastic forming and the H116 heat treatment [1] was chosen to ensure good stress corrosion resistance. The chemistry of the rolled sheet, provided in Table 1, is very similar to the Russian alloy 1535 [2]. As shown in

Table 1. Chemical Composition of C557 Rolled Sheet (in weight percent).

\begin{tabular}{|c|c|c|c|c|c|c|c|}
\hline Sheet Thickness & $\mathrm{Mg}$ & $\mathrm{Sc}$ & $\mathrm{Mn}$ & $\mathrm{Zr}$ & $\mathrm{Zn}$ & $\mathrm{Fe}$ & $\mathrm{Si}$ \\
\hline $1.6 \mathrm{~mm}$ & 3.94 & 0.22 & 0.62 & 0.100 & 0.016 & 0.099 & 0.052 \\
\hline $2.3 \mathrm{~mm}$ & 4.02 & 0.24 & 0.62 & 0.096 & 0.015 & 0.095 & 0.062 \\
\hline
\end{tabular}


Fig. 1, the resulting sheet exhibits very thin pancake shaped grains, aligned in the rolling direction and uniform throughout the thickness. Mg-bearing particles approximately $2 \mu \mathrm{m}$ in size were observed at grain boundaries with occasional Fe, Si-bearing inclusions, ranging from 5 to $20 \mu \mathrm{m}$ in size, as shown in Fig. 2. Results from orientation distribution function (ODF) texture analysis were similar for both sheets and revealed a strong deformation texture, dominated by Brass and shear components, and moderate recrystallization texture.

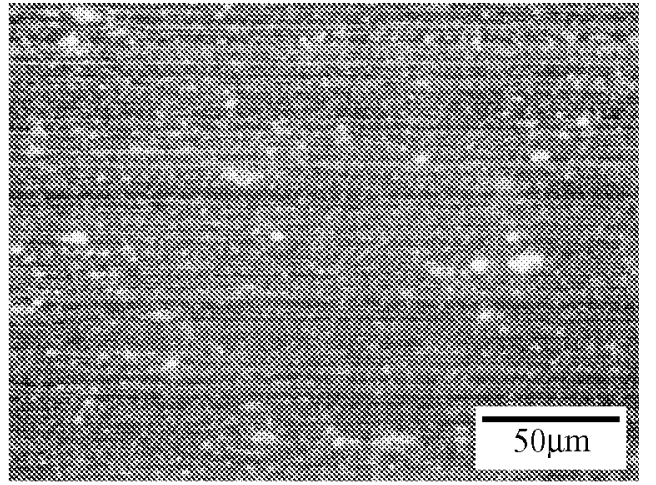

Fig. 1. Typical microstructure of the C557 sheets evaluated.

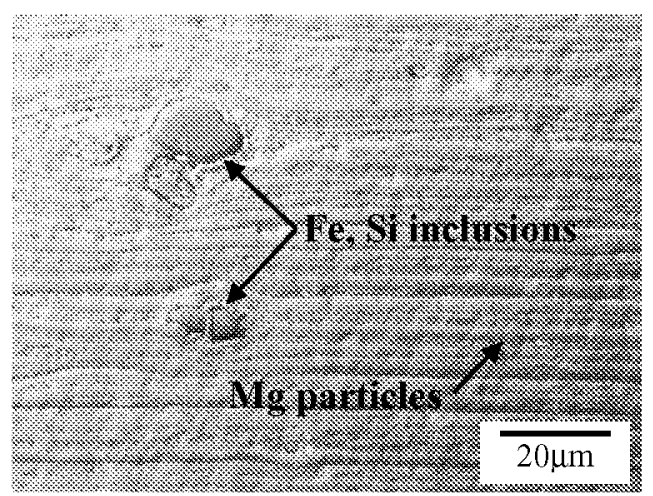

Fig. 2. Nomarski image of the C557 sheet illustrating particle distribution.

\section{Procedures}

Tensile and fracture toughness properties were determined for material in the $\mathrm{H} 116$ condition and after isothermal exposures at $107^{\circ} \mathrm{C}$, for times up to 10,000 hours. Properties were measured for material in the $\mathrm{H} 116$ condition at $25^{\circ} \mathrm{C},-184^{\circ} \mathrm{C}$, and $107^{\circ} \mathrm{C}$. Ambient temperature properties were evaluated after thermal exposure for $1,000,3,000$, and 10,000 hours at $107^{\circ} \mathrm{C}$. The material was isothermally exposed as pieces of sheet from which specimens were machined after exposure.

Tensile properties were measured using sub-size, full sheet thickness specimens in both the longitudinal (L) and transverse (T) orientations. All test procedures were in accordance with ASTM E8-96. For each test, yield strength, ultimate tensile strength, percent elongation to failure (gage length $=2.54 \mathrm{~cm}$ ), and elastic modulus were determined.

Trends in fracture toughness with temperature and thermal exposure were evaluated for both LT and TL orientations using full sheet thickness compact tension (CT) specimens with width, $\mathrm{W}=50.8 \mathrm{~mm}$. Fracture toughness was determined by the single specimen, J-integral method according to ASTM E1152-87. Physical crack length was determined by the potential drop method. The crack initiation toughness $\left(\mathrm{K}_{\mathrm{JI} c i}\right)$, in accordance with ASTM E813-87, and tearing modulus $\left(T_{R}\right)[6]$ were determined from the crack extension data for each test. The fracture surfaces of the $C(T)$ specimens were examined in an scanning electron microscope (SEM) to investigate the fracture mechanisms. Examinations were concentrated at approximately $0.4 \mathrm{~mm}$ and $4 \mathrm{~mm}$ of crack growth in order to characterize fracture morphology under conditions of both plane strain and plane stress, respectively.

Additional fracture toughness tests were performed using middle crack tension, $M(T)$, specimens to determine apparent fracture toughness, $\mathrm{K}_{\mathrm{app}}$, for material in the H116 condition. $\mathrm{M}(\mathrm{T})$ specimens nominally $102 \mathrm{~cm}$ wide were tested in the LT orientation and specimens 
nominally $61 \mathrm{~cm}$ wide were tested in both LT and TL orientations. All M(T) specimens were tested at ambient temperature with procedures in accordance with ASTM E561-94. The stress intensity factor, $\mathrm{K}$, was calculated using Eq. 1,

$$
\mathrm{K}=(\mathrm{P} / \mathrm{BW})[\pi \mathrm{a} \sec (\pi \mathrm{a} / \mathrm{W})]^{1 / 2}
$$

where $\mathrm{P}$ is load, $\mathrm{B}$ is thickness, $\mathrm{W}$ is width, and a is the half crack length. The specimens were fatigue precracked until the crack length to width ratio, $2 \mathrm{aW}$, was approximately 0.33 . Local out-of-plane buckling was restricted during the fracture test and physical crack length was determined by unloading compliance and visual measurement. $\mathrm{K}_{\text {app }}$ was calculated using Eq. 1 based on maximum load $\left(\mathrm{P}=\mathrm{P}_{\max }\right)$ and the initial crack length in the fracture test.

\section{Results and Discussion}

Effect of temperature. Variations in properties with test temperature for material in the H116 condition were similar for both gages of sheet. Tensile results shown in Fig. 3 were consistent with data reported for Al-Mg-Sc alloys [2-4]. Compared with ambient temperature, tensile strengths increased by at least $20 \%$ at $-184^{\circ} \mathrm{C}$ and were reduced by approximately $10 \%$ at $107^{\circ} \mathrm{C}$. Elongation was greater at both $107^{\circ} \mathrm{C}$ and $-184^{\circ} \mathrm{C}$, with values approximately $50 \%$ higher for the transverse orientation and nearly doubled for the longitudinal orientation. Tensile strength anisotropy was low, with values for $\mathrm{L}$ and $\mathrm{T}$ orientations within $5 \%$ at all temperatures. Variations in ductility were greater, with differences between $\mathrm{L}$ and $\mathrm{T}$ orientations exceeding $25 \%$ at ambient temperature.
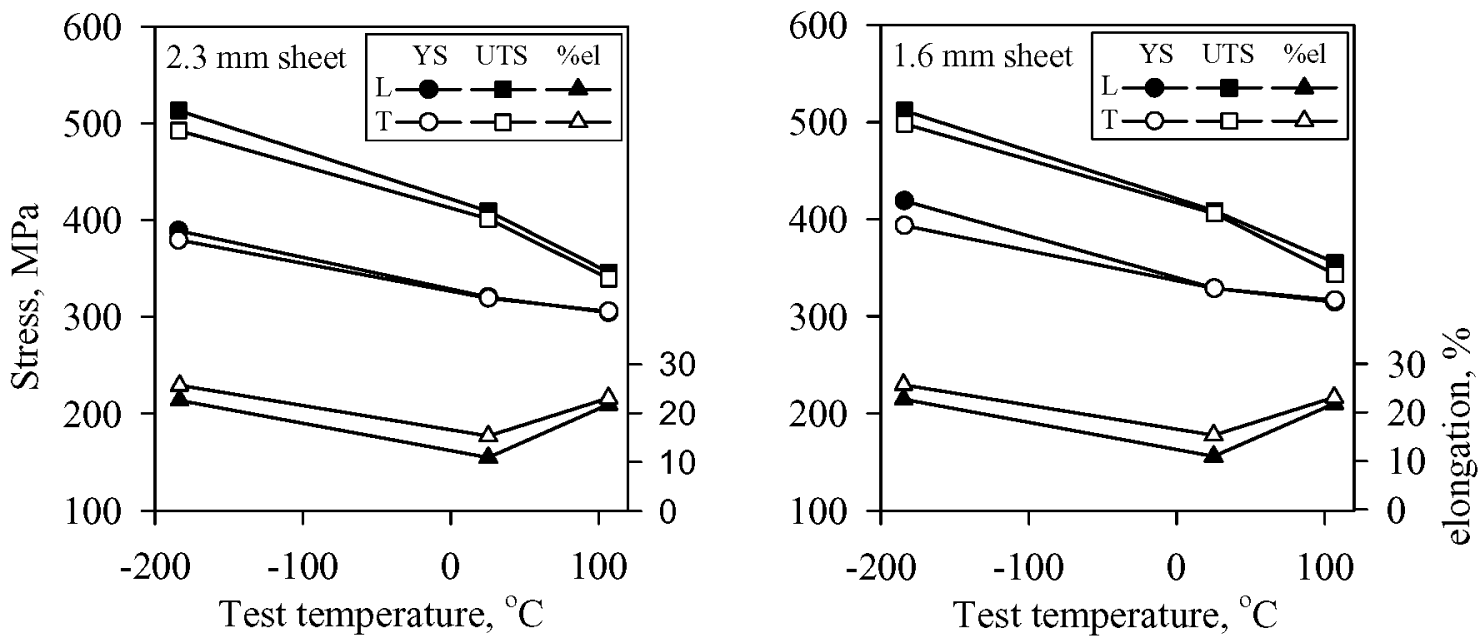

Fig. 3. Effect of test temperature on the tensile properties of C557 sheet in the H116 condition.

Both sheet gages exhibited continuously rising R-curves, shown in Fig. 4, for all temperatures and orientations tested. Higher toughness was achieved at elevated temperature, as evidenced by the overall higher R-curves, but toughness appeared comparable for ambient and cryogenic temperatures. Analysis of the R-curves indicated that initiation toughness, $\mathrm{K}_{\mathrm{JIc} i}$, varied inversely and tearing modulus, $T_{R}$, varied directly with temperature over the range from $-184^{\circ} \mathrm{C}$ to $107^{\circ} \mathrm{C}$, as shown in Fig. 5, with the greatest thermal effect occurring between ambient and elevated temperatures. 

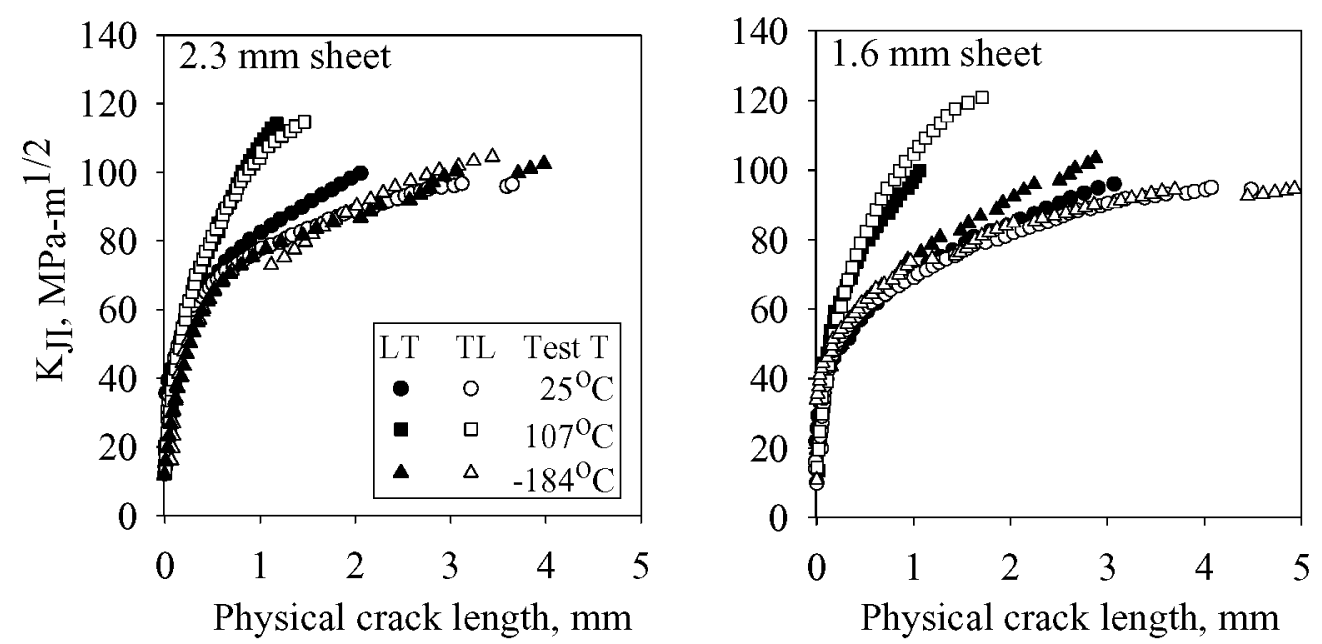

Fig. 4. Variation in $\mathrm{K}_{\mathrm{II} i}$ and $\mathrm{T}_{\mathrm{R}}$ of $\mathrm{C} 557$ sheet with test temperature.
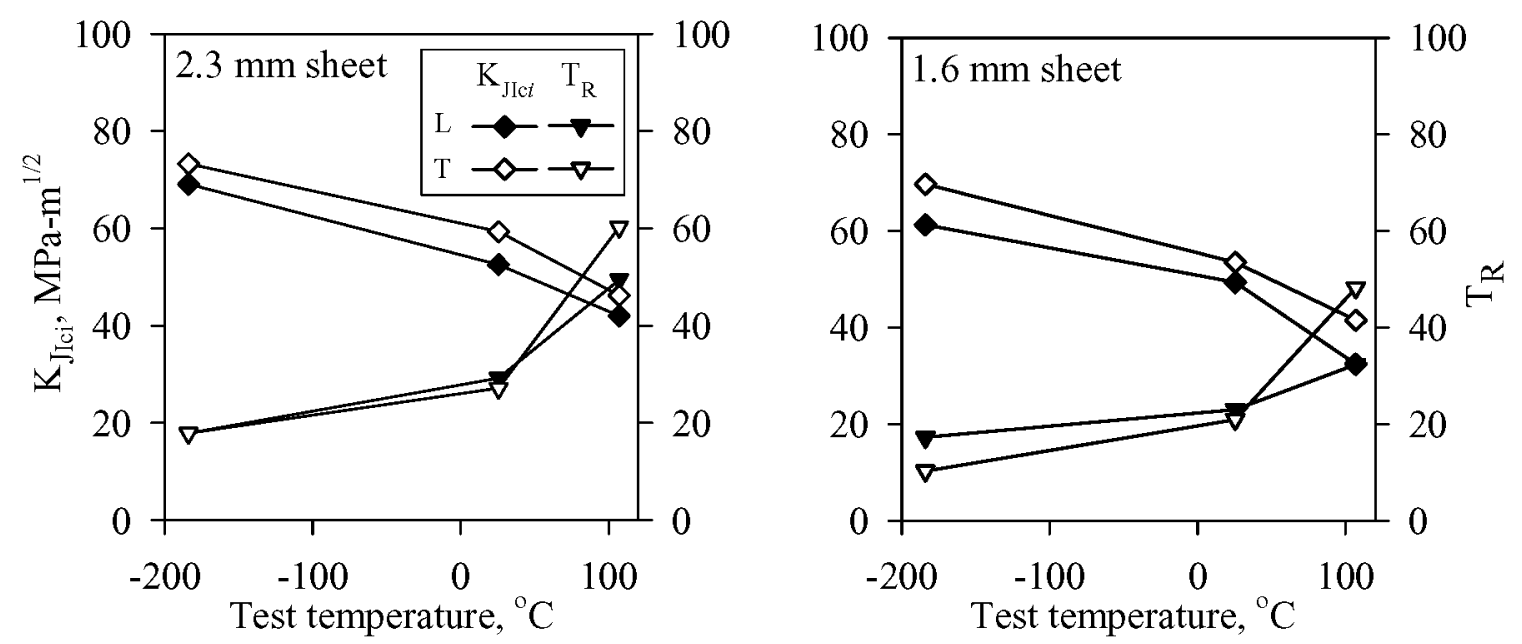

Fig. 5. Variation in $\mathrm{K}_{\mathrm{IIc} i}$ and $\mathrm{T}_{\mathrm{R}}$ of $\mathrm{C} 557$ sheet with test temperature.

SEM examination indicated that the fracture mode was primarily transgranular microvoid coalescence (TGMVC) at ambient temperature. The example shown in Fig. 6 was typical for both plane strain and plane stress fracture. Void initiating particles ranged in size from 1-10 $\mu \mathrm{m}$, resulting in a bimodal distribution of ductile dimples linked by apparent void sheets. The fracture mode at elevated temperature was also TGMVC, however, fracture under plane strain conditions exhibited large, shallow, equiaxed dimples, and an absence of apparent void sheets, which may indicate that the lower initiation toughness reflects primarily the reduced tensile strength at $107^{\circ} \mathrm{C}$. Delaminations, linked by regions of TGMVC, were observed at cryogenic temperature, as shown in Fig. 7. The delaminations, which occur perpendicular to the primary crack plane and parallel to the crack growth direction, begin within $200 \mu \mathrm{m}$ of the fatigue precrack and may explain the enhanced initiation toughness observed. Studies of delamination 
toughening in $\mathrm{Al}-\mathrm{Li}$ alloys indicate that the toughness increase occurs due to reduction of through-thickness constraint at the crack tip associated with the formation of additional free surfaces $[7,8]$.

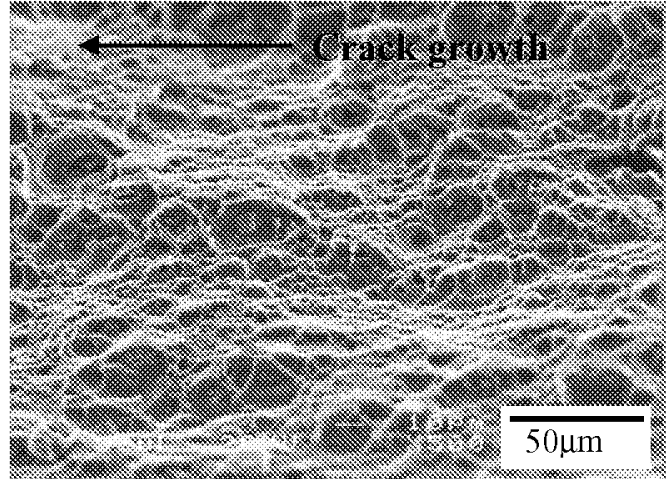

Fig 6. TGMVC typical for plane stress and plane strain fracture at ambient temperature.

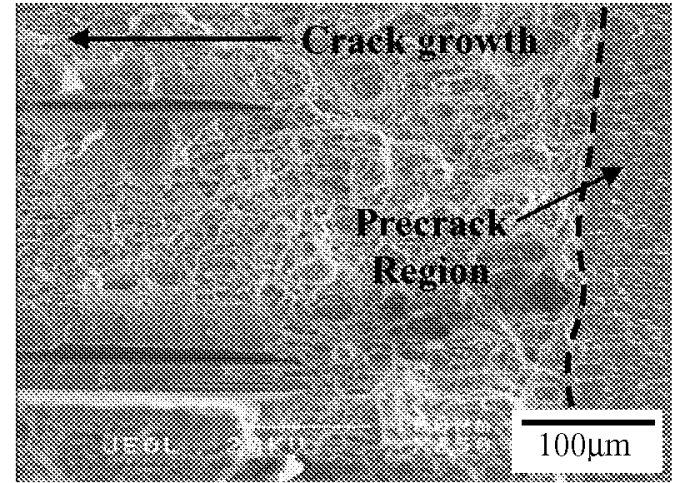

Fig. 7. Delaminations observed in the region of stable crack extension at $-184^{\circ} \mathrm{C}$.

Effect of thermal exposure. The trends in ambient temperature properties with exposure at $107^{\circ} \mathrm{C}$ were similar for both sheet gages. Tensile results shown in Fig. 8 indicate that ultimate and yield strengths were reduced by about $5 \%$ and $10 \%$, respectively, after 10,000 hours exposure at $107^{\circ} \mathrm{C}$. Reductions in elongation after thermal exposure are approximately $20 \%$ for the longitudinal orientation and over $35 \%$ for the transverse orientation, with most of the
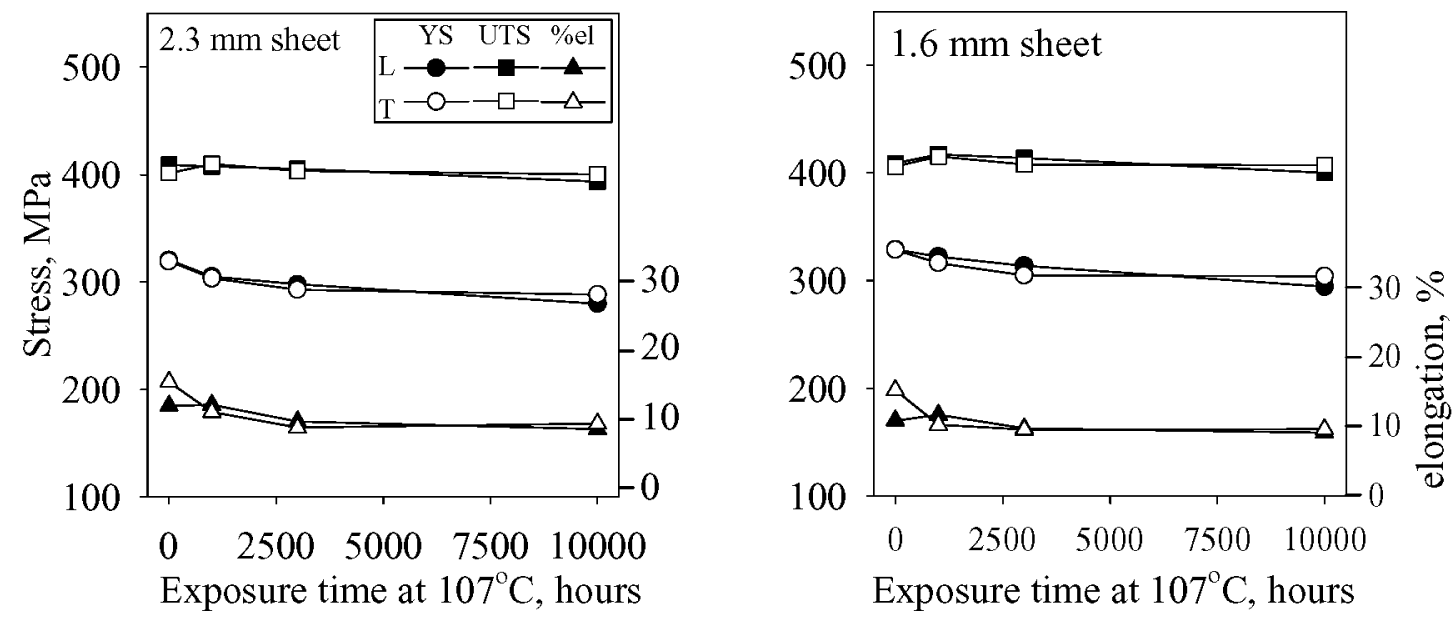

Fig. 8. Variation in tensile properties of C557 sheet with thermal exposure.

reduction occurring by 3,000 hours. Anisotropy in tensile strengths was very low, with values for $\mathrm{L}$ and $\mathrm{T}$ orientations within $3 \%$ for all exposure times. Ductility anisotropy was significantly reduced with thermal exposure. Braun [5] demonstrated that although tensile properties of a similar Al-Mg-Sc alloy remained stable with thermal exposure, corrosion resistance deteriorated due to $\beta$ phase precipitation at grain boundaries. 
The R-curves resulting from ambient temperature tests after thermal exposure, shown in Fig. 9, suggest that toughness remains relatively stable. However, trends in initiation toughness and tearing modulus with thermal exposure, shown in Fig.10, reflect reduction in toughness after 1,000 and 3,000 hours exposure, with recovery to pre-exposure levels by 10,000 hours.
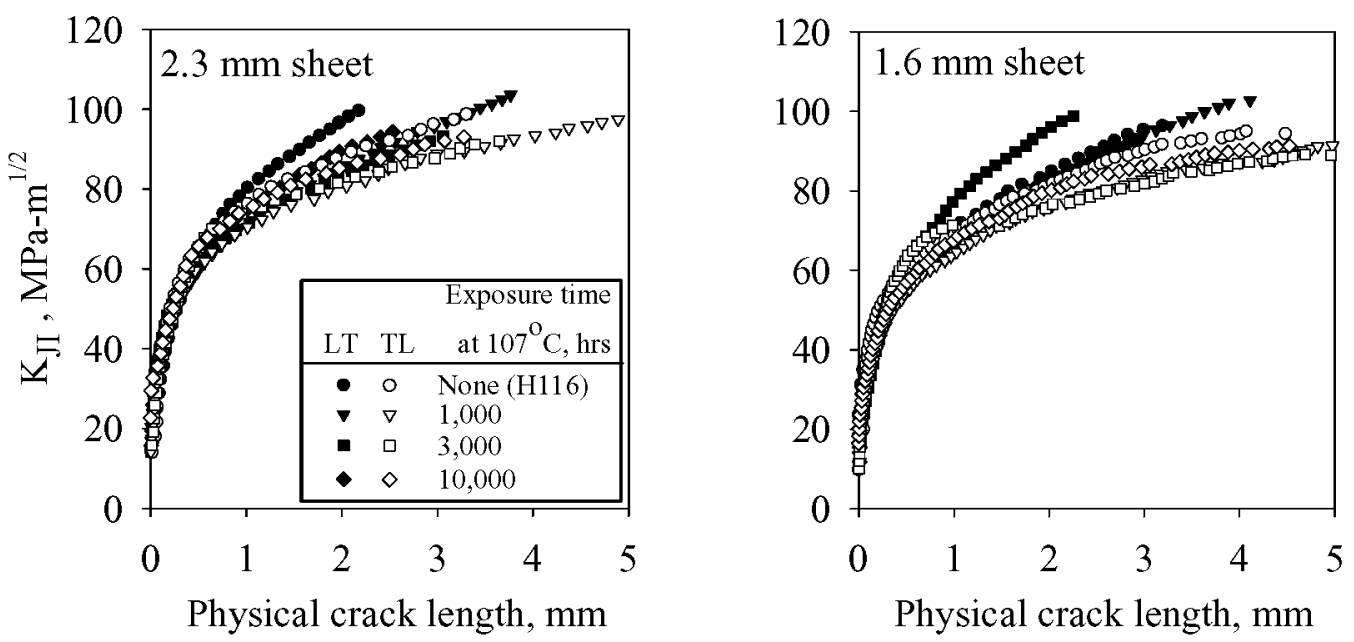

Fig. 9. Variation in R-curves of C557 sheet with exposure time at $107^{\circ} \mathrm{C}$.

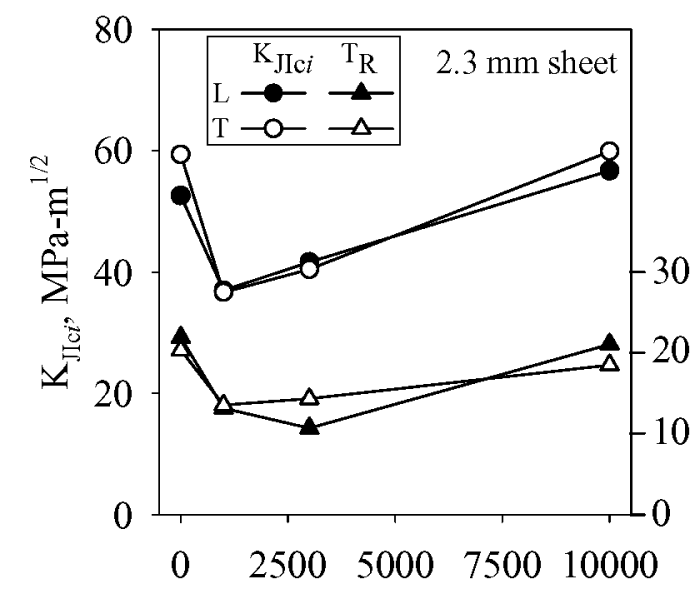

Exposure time at $107^{\circ} \mathrm{C}$, hours

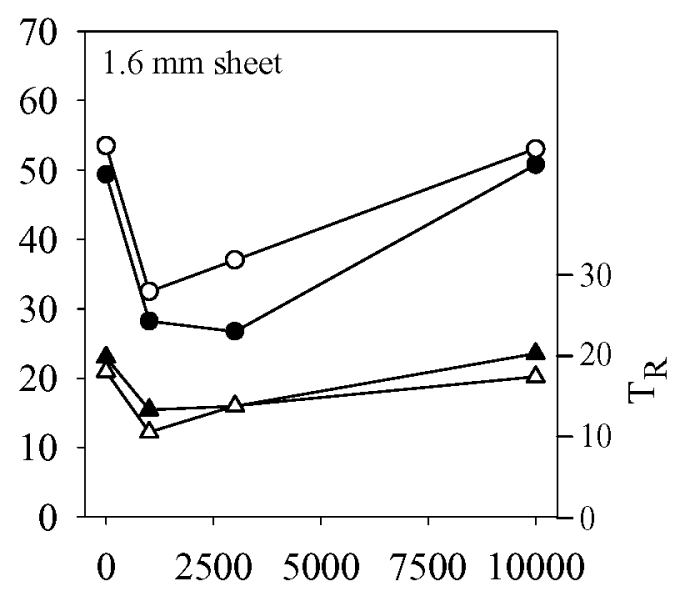

Exposure time at $107^{\circ} \mathrm{C}$, hours

Fig. 10. Variation in $\mathrm{K}_{\mathrm{IIc} i}$ and $\mathrm{T}_{\mathrm{R}}$ of $\mathrm{C} 557$ sheet with exposure time at $107^{\circ} \mathrm{C}$.

SEM fractography indicated that the fracture morphology was similar for all exposure times. Fracture occurred by TGMVC, as shown in Fig. 11. The fraction of large dimples was greater and of apparent void sheets less than observed for unexposed materials, particularly in the plane strain fracture region. Transmission electron microscopy (TEM) analysis of material exposed for 10,000 hours at $107^{\circ} \mathrm{C}$ revealed grain boundary precipitation of the $\beta$ phase, $\mathrm{Al}_{8} \mathrm{Mg}_{5}$. Based on the similarity of fracture surfaces for all thermal exposure conditions, it is likely that precipitation had occurred by 1,000 hours. For specimens exposed for 3,000 and 10,000 hours, delaminations were noted in the fatigue precrack region, as shown in Fig. 12. The transition from the precrack 
to stable crack extension is marked by large plastic deformation zones at the end of each delamination. The resulting crack tip blunting effect may explain the higher initiation toughness values compared with material exposed for 1,000 hours. The delaminations occur over $35 \%$ and $60 \%$ of the sheet thickness for 3,000 and 10,000 hour exposure times, respectively, which could explain the enhanced effect on toughness for longer exposure times.

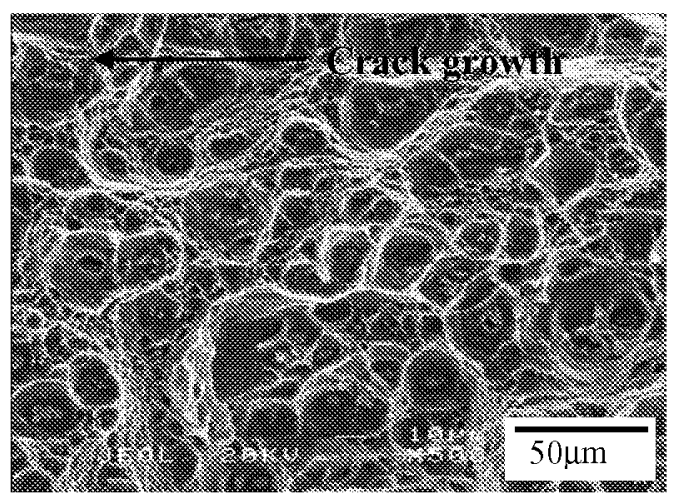

(a) plane strain region

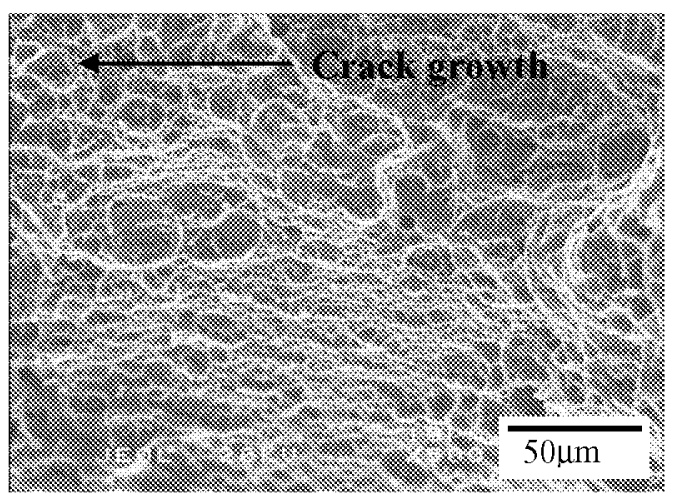

(b) plane stress region

Fig. 11. Typical TGMVC morphology after thermal exposure at $107^{\circ} \mathrm{C}$.

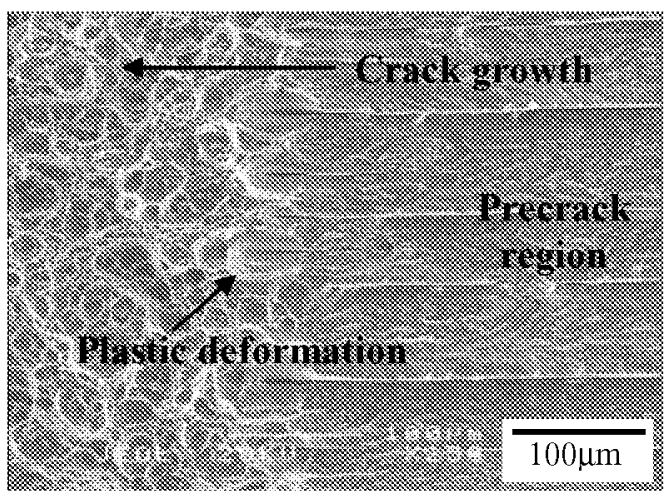

Fig. 12. Delaminations in precrack region after thermal exposure at $107^{\circ} \mathrm{C}$.

$\mathbf{K}_{\text {app }}$ Fracture Toughness Assessment. Airframe manufacturers have traditionally relied on $K_{\text {app }}$ for assessing the fracture toughness of large sheet structures. $K_{\text {app }}$ and tensile yield strength results are provided in Table 2 for C557 compared with values for aerospace alloys evaluated during other in-house research programs. C557 exhibited strength and toughness values comparable to 2024-T3 based on the $61 \mathrm{~cm}$ panels, but exhibited about $12 \%$ lower $\mathrm{K}_{\text {app }}$ in the $102 \mathrm{~cm}$ panels. Overall, the strength-toughness combination for $\mathrm{C} 557$ was lower than for A1-CuMg-Ag alloy, C415, and Al-Li alloy, ML377, which were developed in the High Speed Research program for elevated temperature aircraft service [9]. The toughness level for C557 compared well with 7050 and 7475 , but strengths were lower. 
Table 2. Fracture toughness results from 61 and $102 \mathrm{~cm}$ wide $\mathrm{M}(\mathrm{T})$ panels.

\begin{tabular}{|c|c|c|c|c|c|}
\hline $\begin{array}{c}\text { Alloy/ } \\
\text { Condition }\end{array}$ & $\begin{array}{c}\text { Width, } \\
\mathrm{cm}\end{array}$ & $\begin{array}{c}\text { Thickness, } \\
\mathrm{mm}\end{array}$ & Orientation & YS, MPa & $\begin{array}{c}\mathrm{K}_{\text {app }} \\
\mathrm{MPa}^{1 / 2}\end{array}$ \\
\hline \hline C557-H116 & 102 & 2.3 & L, LT & 320.4 & 126.2 \\
\hline C557-H116 & 102 & 1.6 & L, LT & 328.7 & 124.0 \\
\hline $2024-\mathrm{T3}$ & 102 & 1.6 & L, LT & 310.1 & 142.7 \\
\hline $7475-\mathrm{T} 7$ & 102 & 1.6 & L, LT & 458.9 & 117.2 \\
\hline \hline C557-H116 & 61 & 1.6 & L, LT & 328.7 & 104.7 \\
\hline C557-H116 & 61 & 1.6 & T, TL & 328.0 & 115.5 \\
\hline C557-H116 & 61 & 2.3 & L, LT & 320.4 & 108.6 \\
\hline C557-H116 & 61 & 2.3 & T, TL & 319.0 & 118.0 \\
\hline 2024-T3 & 61 & 1.6 & L, LT & 310.1 & 116.5 \\
\hline C415-T8 & 56 & 2.3 & L, LT & 503.0 & 124.1 \\
\hline ML377-T8 & 56 & 2.3 & L, LT & 526.4 & 120.3 \\
\hline 7050-T73 & 56 & 2.3 & L, LT & 468.5 & 111.1 \\
\hline
\end{tabular}

\section{Conclusions}

Measured mechanical properties for the Al-Mg-Sc alloy C557 and trends with both test temperature and thermal exposure were similar for both 1.6 and $2.3 \mathrm{~mm}$ gage sheet. While strength and toughness both increased at cryogenic temperature, suggesting that C557 is viable for low temperature service, delaminations occured during fracture at $-184^{\circ} \mathrm{C}$ and must be better understood prior to structural applicaton. Thermal stability in tensile properties was demonstrated by less than $5 \%$ variation in ambient temperature tensile strengths with exposure at $107^{\circ} \mathrm{C}$. Fracture toughness decreased with thermal exposure and was primarily due to $\beta$ phase precipitation at grain boundaries. Improvement in fracture toughness with extended thermal exposure was associated with the occurrence of large plastic deformation zones at fatigue precrack delaminations prior to the onset of stable cracking. Yield strength and apparent fracture toughness values of C557 were within $10 \%$ of established values for 2024-T3 sheet, but strength and toughness were somewhat lower than that of alloys developed specifically for elevated temperature service.

\section{References}

[1] J. Hatch, "Aluminum-Magnesium Alloys", Aluminum - Properties And Physical Metallurgy (1984), p. 356.

[2] Y. Filatov, V. Yelagin, V. Zakharov, "New Al-Mg-Sc alloys", Mater. Sci. and Eng. A280 (2000), p. 97.

[3] R. Sawtell and C. Jensen, "Mechanical Properties and Microstructures of Al-Mg-Sc Alloys", Met. Trans. A Vol. 21A (1990), p. 421.

[4] Z. Yin, Q. Pan, Y. Zhang, F. Jiang, "Effect of minor Se and Zr on the microstructure and mechanical properties of Al-Mg based alloys", Mater. Sci. and Eng. A280 (2000), p. 151.

[5] R. Braun, B. Lenczowski, G. Tempus, "Effect of Thermal Exposure on the Corrosion Properties of an Al-Mg-Sc Alloy Sheet”, Mater. Sci. Forum Vol. 331-337 (2000), p. 1647. 
[6] P. Paris, et. al., "The Theory of Instability of the Tearing Mode of Elastic-Plastic Crack Growth", Elastic-Plastic Fracture, ASTM STP 668 (1979), p. 5-36.

[7] J. Wagner, R. Gangloff, "Fracture Toughness of an Al-Li-Cu-In Alloy", Scripta Metall. Vol. 26 (1992), p. 1779.

[8] K. Rao, R. Ritchie, "Mechanisms Influencing the Cryogenic Fracture-Toughness Behavior of Aluminum-Lithium Alloys", Acta Metall. Mater. Vol. 38 No. 11 (1990), p. 2309.

[9] M. Domack, D. Dicus, R. Edahl, D. Chellman, "Effect of Thermal Exposure on the Strength-Toughness Behavior of Elevated Temperature Service Aluminum Alloys", ICAA6 (1998), p. 1081. 


\begin{tabular}{|c|c|c|c|c|}
\hline \multicolumn{3}{|c|}{ REPORT DOCUMENTATION PAGE } & \multicolumn{2}{|r|}{$\begin{array}{l}\text { Form Approved } \\
\text { OMB No. } 0704-0188\end{array}$} \\
\hline \multicolumn{5}{|c|}{ 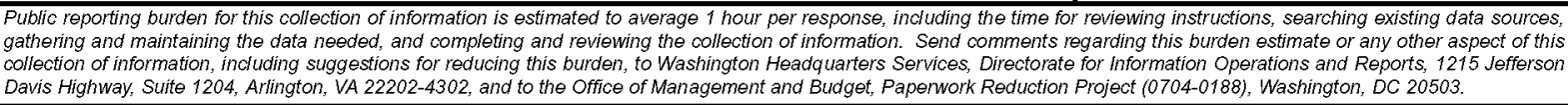 } \\
\hline 1. AGENCY USE ONLY (Leave blank) & $\begin{array}{l}\text { 2. REPORT DATE } \\
\text { April } 2002\end{array}$ & \multicolumn{3}{|c|}{$\begin{array}{l}\text { 3. REPORT TYPE AND DATES COVERED } \\
\text { Technical Memorandum }\end{array}$} \\
\hline \multicolumn{3}{|c|}{$\begin{array}{l}\text { 4. TITLE AND SUBTITLE } \\
\text { Evaluation of Sc-Bearing Aluminum Alloy C557 for Aerospace Applications }\end{array}$} & \multirow{2}{*}{\multicolumn{2}{|c|}{$\begin{array}{l}\text { 5. FUNDING NUMBERS } \\
\text { WU 706-63-61-01 }\end{array}$}} \\
\hline \multicolumn{3}{|c|}{$\begin{array}{l}\text { 6. AUTHOR(S) } \\
\text { Marcia S. Domack and Dennis L. Discus }\end{array}$} & & \\
\hline \multicolumn{3}{|c|}{$\begin{array}{l}\text { 7. PERFORMING ORGANIZATION NAME(S) AND ADDRESS(ES) } \\
\text { NASA Langley Research Center } \\
\text { Hampton, VA 23681-2199 }\end{array}$} & \multicolumn{2}{|c|}{$\begin{array}{l}\text { 8. PERFORMING ORGANIZATION } \\
\text { REPORT NUMBER } \\
\text { L-18161 }\end{array}$} \\
\hline \multicolumn{3}{|c|}{$\begin{array}{l}\text { 9. SPONSORING/MONITORING AGENCY NAME(S) AND ADDRESS(ES) } \\
\text { National Aeronautics and Space Administration } \\
\text { Washington, DC 20546-0001 }\end{array}$} & \multicolumn{2}{|c|}{$\begin{array}{l}\text { 10. SPONSORING/MONITORING } \\
\text { AGENCY REPORT NUMBER } \\
\text { NASA/TM-2002-211633 }\end{array}$} \\
\hline \multicolumn{5}{|l|}{ 11. SUPPLEMENTARY NOTES } \\
\hline \multicolumn{3}{|c|}{$\begin{array}{l}\text { 12a. DISTRIBUTION/AVAILABILITY STATEMENT } \\
\begin{array}{ll}\text { Unclassified-Unlimited } & \\
\text { Subject Category } 26 & \text { Distribution: Standard } \\
\text { Availability: NASA CASI (301) } 621-0390\end{array}\end{array}$} & \multicolumn{2}{|c|}{ 12b. DISTRIBUTION CODE } \\
\hline \multicolumn{5}{|c|}{$\begin{array}{l}\text { 13. ABSTRACT (Maximum 200 words) } \\
\text { The performance of the Al-Mg-Sc alloy C557 was evaluated to assess its potential for a broad range of aerospace } \\
\text { applications, including airframe and launch vehicle structures. Of specific interest were mechanical properties at } \\
\text { anticipated service temperatures and thermal stability of the alloy. Performance was compared with conventional } \\
\text { airframe aluminum alloys and with other emerging aluminum alloys developed for specific service environments. } \\
\text { Mechanical properties and metallurgical structure were evaluated for commercially rolled sheet in the as-received } \\
\text { H116 condition and after thermal exposures at } 107^{\circ} \mathrm{C} \text {. Metallurgical analyses were performed to define grain mor- } \\
\text { phology and texture, strengthening precipitates, and to assess the effect of thermal exposure. }\end{array}$} \\
\hline \multirow{2}{*}{\multicolumn{4}{|c|}{$\begin{array}{l}\text { 14. SUBJJCT TERMS } \\
\text { Al-Mg-Sc alloys, C557, tensile, fracture toughness, thermal exposure }\end{array}$}} & $\begin{array}{l}\text { 15. NUMBER OF PAGES } \\
14\end{array}$ \\
\hline & & & & 16. PRICE CODE \\
\hline $\begin{array}{l}\text { 17. SECURITY CLASSIFICATION } \\
\text { OF REPORT } \\
\text { Unclassified }\end{array}$ & $\begin{array}{l}\text { 18. SECURITY CLASSIFICATION } \\
\text { OF THIS PAGE } \\
\text { Unclassified }\end{array}$ & $\begin{array}{l}\text { 19. SECURITY CLASSII } \\
\text { OF ABSTRACT } \\
\text { Unclassified }\end{array}$ & FICATION & $\begin{array}{l}\text { 20. LIMITATION } \\
\text { OF ABSTRACT } \\
\text { UL }\end{array}$ \\
\hline NSN 7540-01-280-5500 & & & & $\begin{array}{l}\text { Standard Form } 298 \text { (Rev. 2-89) } \\
\text { Prescribed by ANSI Std. Z39-18 } \\
298-102\end{array}$ \\
\hline
\end{tabular}

